\title{
Review
}

Source: The Musical Times and Singing Class Circular, Vol. 42, No. 702 (Aug. 1, 1901), p. 547 Published by: Musical Times Publications Ltd.

Stable URL: http://www.jstor.org/stable/3366203

Accessed: 20-04-2016 12:50 UTC

Your use of the JSTOR archive indicates your acceptance of the Terms \& Conditions of Use, available at

http://about.jstor.org/terms

JSTOR is a not-for-profit service that helps scholars, researchers, and students discover, use, and build upon a wide range of content in a trusted digital archive. We use information technology and tools to increase productivity and facilitate new forms of scholarship. For more information about JSTOR, please contact support@jstor.org.

Musical Times Publications Ltd. is collaborating with JSTOR to digitize, preserve and extend access to The Musical Times and Singing Class Circular 
Twenty-five Songs. By Ernest Lavigne.

[Montreal: Sohmer Park.]

THE development of music on the other side of the Atlantic is one of the many signs of progress in intellectual pursuits in which true joys are to be found. Mr. Lavigne is one of the most prominent musicians in the city of Montreal, and judging by this collection of songs his reputation has been well earned. Although the settings are unpretentious and simple in design and character, they are very vocal and the music is in thorough sympathy with the text, which has been selected from the best-known modern French poets. 'Vous aimerez demain' and 'Tristesse d'Amour,' words by Armand Silvestre; and 'Absence,' words by Théophile Gautier, are pleasing examples of expressive vocal writing. An English translation is supplied, but the accentuation is very faulty. In the first page the second syllable of the words 'verdant,' 'winter,' 'trembling,' and 'morning,' comes on the first beat of the bar!

\section{CHURCH MUSIC.}

Communion Service in C. By John Stainer.

[Novello and Company, Limited.]

AnY composition by the late Sir John Stainer possesses peculiar interest, and the setting of this Communion Service, composed expressly for the choir of St. Paul's Cathedral, where Sir John rendered such faithful and memorable service, attests to his talent and keen sympathy of the spirit of Anglican Church music. The music is set out for first and second sopranos, altos, tenors, and first and second basses, and is for unaccompanied singing. The service includes the Kyrie, Credo, Sanctus, and Gloria in Excelsis, and of these the most important, musically, is the Credo. Its opening phrase expresses the firmness of conviction which should accompany the declaration of belief, and its repetition at the opening of the Gloria in Excelsis is a distinctly happy thought. The Sanctus is very simple and impressive. The first and second basses sing a continuous and flowing counterpoint through the greater part of the number, while the other voices whisper the words 'Holy, holy, Lord God of Hosts.' The conclusion is reached by a finely worked-up climax.

In the Lord put I my trust. By Charles Macpherson.

Wisdom shall praise herself. By John E. West.

Blessed are the pure in heart. By A. Davidson Arnott.

Far from the world, O Lord, and Now sinks the sun. By Horatio W. Parker.

The people that walked in darkness. By Charles F. Bowes.

Thou art gone to the grave. By C. Lee Williams.

[Novello and Company, Limited.]

THE first of this sextet of anthems contains much that testifies to the talent and cultured musicianship of $\mathrm{Mr}$. Charles Macpherson. Dramatic perception restrained by recognition of means appropriate to the Church, and governed by a knowledge of what is effective, are prominent features on every page. The setting of the phrase 'and what hath the righteous done? ' which commences fortissimo and ends piano, and the subsequent repetition of the single word 'What ?' sung pianissimo to the chord of the relative minor of the preceding harmony, is an instance of the happy expression of the inner meaning of the text which distinguishes the music.

The text of Mr. West's anthem has been selected by $\mathrm{Mr}$. John S. Bumpus, and is of uncommon character, being taken from the twenty-fourth chapter of Ecclesiasticus. It is, however, none the less suitable for musical illustration, and has been set in a simple but effective manner. The familiar Beatitude, 'Blessed are the pure in heart,' has been allied to music of devotional and flowing character by Mr. Arnott, and the anthem merits wide-spread recognition from choirmasters. Attention may be called to the freshness of the final cadence.
The words of 'Far from the world,' are by the poet Cowper, and the naïve lines have been set by Professor Parker to music thoroughly in sympathy with their spirit. The anthem opens with a solo, designed for soprano or tenor, the melody of which is subsequently repeated by the choir in four-part harmony. Afterwards the soloist superimposes a fifth part. The music is not only easy to sing, but grateful to those who sing it. 'Now sinks the sun' is an unaccompanied chorus from Professor Parker's oratorio 'St. Christopher.' The music requires a choir of some magnitude, the parts being occasionally doubled. It also demands well-trained voices, but these essentials being forthcoming, the anthem would be impressive. $\mathrm{Mr}$. Bowes has written in a direct and simple manner that render his anthem well suited to choirs of moderate ability. The soprano solo is melodious, and the final fughetta is bright and vigorous. Mr. Lee Williams's anthem is written 'In Memoriam, South Africa, Igoo.' The text is Bishop Heber's well-known hymn, which has been set in simple but expressive fashion that intensifies the significance of the lines.

\section{VIOLIN AND VIOLONCELLO MUSIC.}

Reverie. For violin, with pianoforte accompaniment. By" M. Fallas Shaw.

Elegie. By H. Waldo Warner. Transcribed for violoncello by Tennyson Werg.

Cradle Song. For violin, with piano accompaniment. By W. H. Bell.

[Novello and Company, Limited.]

Mr. SHAw has written a charming little solo for the violin, with an interesting musicianly accompaniment. Mr. Warner's 'Elegie' is even more beautiful for the 'cello than the violin, and Mr. Bell's Cradle Song is a very pleasing solo.

Consolation. Pour Violoncelle avec accompagnement de Piano. By W. H. Squire.

[Bosworth and Co.]

Ah! Moon of my delight. Recit. and Air. Transcribed for violin, with piano accompaniment. By Liza Lehmann. [Metzler and Co.]

THE first of these two pieces is effectively written for the instrument and of moderate difficulty, and will find many admirers. The second is a very excellent transcription of one of the most beautiful numbers in the fascinating songcycle 'In a Persian Garden.'

\section{ROYAL ACADEMY OF MUSIC.}

$$
\text { 'MIGNON.' }
$$

THE enterprise of the management of the Royal Academy of Music in engaging a theatre for the performance of their students is to be highly commended. The advantage of environment to young artists is invaluable, and much experience is to be gained by appearing in a modern theatre. At the first of the two performances of the opera of 'Mignon' at the Globe Theatre on the I6th and 17 th ult., the name-part was interpreted with much charm by Miss Ida Mann, who possesses a rich-toned mezzo-soprano voice, in addition to considerable dramatic perception and admirable clearness of articulation-qualities which should enable her to become an acceptable artist. The character of Filina was sustained by Miss Lilian Kent, whose most successful achievement was the neatness with which she executed the florid passages which abound in this part. The hero, Wilhelm, was personated by Mr. Edward F. Barrow, who, although he has a tenor voice of pleasing quality, especially in the upper register, has yet much to learn. Mr. Charles Thompson showed histrionic aptitude as Laertes, and the other characters were efficiently sustained by Miss Daisy Drewe, Miss Jennie Bateman and Messrs. George Clowser, Henry Rojas, Walter Monck, and Harold R. Hammond.

At the second performance the heroine was impersonated by Miss Edith Hensler, who gave proof, especially in the latter scenes, of much intelligence and dramatic perception. The part of Filina was sung by Miss Wheeler 